\title{
4 MENINGIOMA
}

\author{
Martin C. Tom, David J. Schwartz, and Abigail L. Stockham
}

QUICK HIT Meningiomas are the most common primary brain tumors in adults, representing approximately $40 \%$ of all primary brain tumors with $\sim 30,500$ cases per year in the United States, $80 \%$ of which are WHO grade I. ${ }^{1-3}$ Asymptomatic grade I meningiomas can be observed, whereas maximal safe surgical resection is otherwise the standard of care for lesions that are surgically accessible. The extent of surgical resection and grade of meningioma determine initial postsurgical approach (see Table 4.1). Recurrent meningiomas are generally managed with re-resection followed by RT when no previous RT has been administered. Unresectable meningiomas are managed with fractionated RT or SRS, depending on grade, size, and location. Similar strategies are employed in the setting of spinal meningiomas (approximately 10\% of cases). While the vast majority of meningiomas are benign, they may ultimately cause significant morbidity and mortality. Particularly in young patients, the likelihood and morbidity of recurrence must be weighed against the potential long-term sequelae of RT to the brain. Grade II meningiomas have an intermediate prognosis, while grade III meningiomas are aggressive with high recurrence and mortality rates. Recurrent meningiomas have higher subsequent recurrence rates than newly diagnosed meningiomas, adding further complexity to management decisions.

\begin{tabular}{|c|c|c|c|}
\hline $\begin{array}{l}\text { Extent of } \\
\text { Resection }\end{array}$ & WHO Grade I & WHO Grade II & WHO Grade III \\
\hline GTR & Observe & $\begin{array}{l}\text { EBRT 54-59.4 Gy/30-33 } \\
\text { fx }\end{array}$ & 60-66 Gy/30-33 fx \\
\hline STR & $\begin{array}{l}\text { Observe OR } \\
\text { EBRT } 54 \text { Gy/30 fx OR } \\
\text { SRS 12-14 Gy }\end{array}$ & $59.4-60$ Gy/30-33 fx & $60-66$ Gy/30-33 fx \\
\hline Recurrent disease & $\begin{array}{l}\text { Consider further } \\
\text { resection + EBRT } 54 \\
\text { Gy/30 fx OR } \\
\text { SRS 12-14 Gy }\end{array}$ & $\begin{array}{l}\text { Consider further } \\
\text { resection + 59.4-60 } \\
\text { Gy/30-33 fx OR } \\
\text { SRS 16 Gy }\end{array}$ & $\begin{array}{l}\text { Consider further } \\
\text { resection } 60-66 \\
\text { Gy/30-33 fx OR } \\
\text { SRS 18-24 Gy (based } \\
\text { on size) }\end{array}$ \\
\hline $\begin{array}{l}\text { Unresectable } \\
\text { disease }\end{array}$ & $\begin{array}{l}\text { EBRT } 54 \mathrm{~Gy} / 30 \mathrm{fx} \\
\text { OR } \\
\text { SRS 12-14 Gy }\end{array}$ & $\begin{array}{l}59.4-60 \mathrm{~Gy} / 30-33 \text { fx OR } \\
\text { SRS } 16 \text { Gy }\end{array}$ & $\begin{array}{l}\text { 60-66 Gy/30-33 fx OR } \\
\text { SRS 18-24 Gy (based } \\
\text { on size) }\end{array}$ \\
\hline
\end{tabular}

EPIDEMIOLOGY: 30,551 cases per year in the United States; approximate 1-, 5-, and 10-year survival rates are $80 \%, 65 \%$, and $58 \%$, respectively (decreased survival rate with increasing age). Incidence increases with age (especially $>65) .{ }^{1}$ There is approximately a 2:1 female predominance though males are slightly more likely to have atypical or malignant meningiomas. ${ }^{1,2}$

RISK FACTORS: Older age, ionizing radiation, NF2, MEN1, exogenous/endogenous hormones, elevated BMI, decreased physical activity, increased height (women), uterine fibroids, and breast cancer. $^{2,4-10}$ The degree to which estrogen exposure is an independent risk factor from BMI, decreased physical activity, increased height, uterine fibroids, and breast cancer is unclear.

ANATOMY: Arises from the arachnoid layer of the meninges between the dura mater and pia mater, commonly at sites of high density of arachnoid villi and associated arachnoid cap cells. Most frequently noted at supratentorial sites of dural reflection, such as at the cerebral convexity $(\sim 20 \%)$ and parafalcine/parasagittal $(\sim 25 \%)$, along the sphenoid wing $(\sim 20 \%)$ and skull base (resulting in decreased surgical accessibility), intraventricular and suprasellar region, and olfactory groove $(\sim 10 \%)$ and in the posterior fossa most commonly along the petrous bone $(\sim 10 \%)$. 
PATHOLOGY: Classified by the WHO into three grades: WHO grade I (benign), WHO grade II (atypical, yet still benign), and WHO grade III (malignant).

\begin{tabular}{|c|c|c|c|c|}
\hline $\begin{array}{l}\text { WHO } \\
\text { Grade }\end{array}$ & Frequency & Subtypes & Characteristics & $\begin{array}{l}\text { Recurrence } \\
\text { After GTR }\end{array}$ \\
\hline Grade I & $80 \%$ & $\begin{array}{l}\text { Meningothelial } \\
\text { Fibroblastic } \\
\text { Transitional } \\
\text { Psammomatous } \\
\text { Angiomatous } \\
\text { Microcystic } \\
\text { Secretory } \\
\text { Metaplastic } \\
\text { Lymphoplasmacyte- } \\
\text { rich }\end{array}$ & $\begin{array}{l}\text { Psammoma bodies } \\
\text { Cellular whorls } \\
\text { Calcifications }\end{array}$ & $7 \%-25 \%$ \\
\hline $\begin{array}{l}\text { Grade } \\
\text { II }\end{array}$ & $18 \%$ & $\begin{array}{l}\text { Chordoid } \\
\text { Clear cell } \\
\text { Atypical }\end{array}$ & $\begin{array}{l}\geq 4 \text { mitoses/10 HPF, brain invasion } \\
\text { OR } \geq 3 \text { features below: } \\
\text { - Hypercellularity } \\
\text { - Small cells w / high } \\
\text { nuclear:cytoplasm ratio } \\
\text { - Prominent nucleoli } \\
\text { - Patternless / sheet-like growth } \\
\text { - Foci of spontaneous necrosis }\end{array}$ & $29 \%-52 \%$ \\
\hline $\begin{array}{l}\text { Grade } \\
\text { III }\end{array}$ & $2 \%$ & $\begin{array}{l}\text { Anaplastic } \\
\text { Papillary } \\
\text { Rhabdoid }\end{array}$ & $\begin{array}{l}\geq 20 \text { mitoses/10 HPF } \\
\text { and/or } \\
\text { - Carcinomatous features } \\
\text { - Sarcomatous features } \\
\text { - Melanomatous features } \\
\text { - Loss of usual growth pattern } \\
\text { - Brain invasion } \\
\text { - Abundant mitoses with atypia } \\
\text { - Multifocal necrotic foci }\end{array}$ & $50 \%-94 \%$ \\
\hline
\end{tabular}

GENETICS: Genetic mutations are common, but the clinical impact of mutations is evolving. DNA methylation profiling and other molecular signatures are promising to better risk-stratify meningiomas. ${ }^{11}$ Relevant molecular alterations include TERT, PIK3CA, POLR2A, SMO, KLF4, AKT1, TRAF7, NF2, and SUFU. ${ }^{12}$

CLINICAL PRESENTATION: May be asymptomatic. If symptomatic: headaches, seizure, altered cognition, focal neurologic deficit— these are further detailed in Table 4.3 (data modified from Raizer). ${ }^{13}$

TABLE 4.3: Common Presenting Symptoms of Meningioma Based on Location

Parasagittal: motor and/or sensory changes

Frontal: personality change, avolition, executive dysfunction, disinhibition, urinary incontinence, Broca's aphasia

Temporal: memory changes, Wernicke aphasia (left), aprosody (right), olfactory symptoms including seizures

Cavernous sinus: CN symptoms (nerves III, IV, V1-V2, VI pass through the cavernous sinus), decreased visual acuity, impaired extraocular motion with resultant diplopia, numbness

Occipital lobe: visual field deficit

Cerebellopontine angle: unilateral deafness/decreased hearing, facial numbness, facial weakness

Optic nerve sheath: ipsilateral decreased visual acuity/blindness, exophthalmos, ipsilateral pupillary dilation nonreactive to direct light but with retained consensual contraction

Sphenoid wing: cranial neuropathy, seizures

Tentorium: extra-axial compression with associated occipital/parietal/cerebellar symptoms

Foramen magnum: paraparesis, urinary/anal sphincter dysfunction, tongue atrophy \pm fasciculation

Spinal canal: back pain, Brown-Séquard (hemispinal cord) syndrome 
WORKUP: H\&P with attention to the neurologic exam, head CT, MRI brain to evaluate for a well-circumscribed, classically homogeneously enhancing extra-axial mass with a dural tail (present in more than half of meningiomas-may also be present in patients with chloroma, lymphoma, and sarcoidosis). Meningiomas are T1 isointense and CT isodense with normal brain parenchyma unless contrast is administered, underscoring the importance of IV contrast when possible. Evaluate for bone invasion and/or reactive hyperostosis. Modest perilesional edema may be present; this is more frequently encountered with rapidly enlarging atypical and/or malignant meningiomas as well as convexity or parasagittal meningiomas. Extensive perilesional edema is a relative contraindication to SRS as patients may have considerable posttreatment edema following treatment of convexity meningiomas.

PROGNOSTIC FACTORS: Poorer prognosis with increasing grade, decreasing extent of resection, proliferative index $(\mathrm{Ki}-67)>1 \%$, brain invasion, age $<45$, chromosomal abnormalities involving 14 and 22, aggressive clinical behavior, p53 overexpression. ${ }^{14-20}$

NATURAL HISTORY: Approximately 1 to $2 \mathrm{~mm}$ of growth annually for grade I meningiomas. Most failures occur locally, and local progression can further aggravate associated neurologic symptoms. Marginal failure around the meninges is possible, particularly with high-grade meningioma.

\section{TREATMENT PARADIGM}

Observation: Observation may be appropriate for incidentally discovered small, asymptomatic meningiomas. Observation is also appropriate for WHO grade I tumors following GTR and may be considered following STR as well. Surveillance with MRI is recommended annually for patients with WHO grade I meningiomas undergoing observation to assess need for treatment.

Surgery: Standard is maximal safe surgical resection. Often requires craniotomy, but for sphenoid wing/skull base lesions, endoscopic surgery may be indicated. Simpson grade correlates with local failure (Table 4.4). Postoperative brain MRI should be obtained within 48 hours of surgery.

\begin{tabular}{|l|l|l|}
\hline \multicolumn{2}{|l|}{ TABLE 4.4: Simpson Grading System for Meningioma Resection } & $\begin{array}{l}\text { Recurrence Rate at } 5 \\
\text { Years (\%) }\end{array}$ \\
\hline Grade & Extent of Resection & 0 \\
\hline $\mathbf{0}$ & $\begin{array}{l}\text { GTR, including dural attachment and bone plus stripping of } \\
\text { 2-4-cm dura }\end{array}$ & 9 \\
\hline $\mathbf{1}$ & GTR, including dural attachment and any abnormal bone & 19 \\
\hline $\mathbf{2}$ & GTR, with coagulation instead of resection of dural attachment & 29 \\
\hline $\mathbf{3}$ & $\begin{array}{l}\text { GTR of meningioma without resection or coagulation of dural } \\
\text { attachment }\end{array}$ & 44 \\
\hline $\mathbf{4}$ & Subtotal resection & N/A \\
\hline $\mathbf{5}$ & Tumor debulking or decompression only & 29 \\
\hline
\end{tabular}

Chemotherapy: No primary role for CHT. Although medical therapy is nonstandard, 2020 NCCN guidelines suggest patients with radiographic progression may benefit from bevacizumab to prevent rapid neurologic deterioration. ${ }^{21}$

\section{Radiation}

Dose: WHO grade I meningiomas generally are treated to $50.4 \mathrm{~Gy} / 28 \mathrm{fx}$ or $54 \mathrm{~Gy} / 30 \mathrm{fx}$. WHO grade II meningiomas are treated to $59.4 \mathrm{~Gy} / 33 \mathrm{fx}$ or $60 \mathrm{~Gy} / 30 \mathrm{fx}$. WHO grade III meningiomas are treated to 60-66 Gy/30-33 fx. See RTOG 0539 for common dosing strategy. SRS dose, when feasible, is 12 to $14 \mathrm{~Gy}$ for grade I tumors. When surrounding tissues allow, $16 \mathrm{~Gy}$ for grade II tumors may be considered as well as RTOG 9005 dosing for grade III tumors (18-24 Gy). Brachytherapy is utilized at select institutions for multiply recurrent meningiomas. 


\section{EVIDENCE-BASED Q\&A}

- Do incidentally discovered meningiomas require aggressive intervention?

Incidentally appreciated meningiomas may not require additional intervention. In at least one study, more than half of patients' meningiomas demonstrated no growth at 5 years. These patients may be followed with imaging at 3 to 6 months and then annually thereafter if no growth is appreciated. ${ }^{23}$

What is the optimal first-line management in the treatment of meningiomas?

Maximal safe surgical resection provides the greatest opportunity for minimizing recurrence rates. The extent of resection is graded according to the Simpson grading system, which was the foundational study in meningioma. ${ }^{24}$

Mayo Clinic (Mayo Clin Proc 1998, PMID 9787740): RR of 581 patients treated with initial resection. GTR in $80 \%$. The 5- and 10-year PFS was $88 \%$ and $75 \%$ for GTR but only $61 \%$ and $39 \%$ for less than GTR. Perioperative mortality was $1.6 \%$. A matched cohort analysis suggested nontrivial increase in morbidity and mortality from meningioma and/or treatment. Many of the risk factors for recurrence we use today were noted in this study. Comment: Used an older data set. Surgical techniques, radiographic evaluation, and perioperative care may have improved since that time. ${ }^{16}$

\section{What is the role of RT in the management of WHO grade I meningiomas?}

GTR (Simpson 1-3) is generally considered definitive, and patients may be followed with surveillance imaging. However, with longer follow-up, recurrence rates as high as 20\%,40\%, and 60\% have been reported at 5, 10, and 15 years, likely reflecting modern imaging capabilities. ${ }^{16,25-27} R T$ is typically reserved for salvage for these patients. For those with STR (Simpson 4-5), recurrence rates of $40 \%$ at 5 years and $60 \%$ at 10 years can be reduced to those of GTR (approximately halved) with adjuvant RT doses $>50.4 \mathrm{~Gy} .{ }^{28,29}$

\section{What is the role of RT in the management of WHO grade II meningiomas?}

Adjuvant $R T$ is generally recommended after GTR and strongly recommended after STR. Adjuvant RT after GTR of a WHO grade II meningioma is 54 Gy per RTOG 0539. After STR of a WHO grade II, adjuvant $R T$ to $59.4 \mathrm{~Gy} / 33 \mathrm{fx}$ or $60 \mathrm{~Gy} / 30 \mathrm{fx}$ is recommended to minimize risk of LR based on multiple retrospective series. ${ }^{30-34}$ Without RT, LR rates of up to $60 \%$ at 5 years and CSS of only $70 \%$ at 10 years have been observed. ${ }^{25,35}$ Following GTR (Simpson 1-2), 5-year PFS is roughly doubled, from approximately $40 \%$ to $80 \%$ with adjuvant RT. ${ }^{31,36}$ Following STR, adjuvant RT is strongly recommended due to high recurrence rates.

\section{Can RT margins be reduced in patients with WHO grade II meningioma treated with IMRT?}

Although RTOG 0539 used at least a 1-cm CTV expansion for WHO grade II meningiomas, retrospective data suggest a 5-mm CTV and a 3-mm PTV may be used without undue risk of LR. ${ }^{26}$

\section{What is the role of RT in the management of WHO grade III meningiomas?}

Adjuvant $R T$ is necessary regardless of resection extent. WHO grade III meningiomas are relatively rare, with less than 300 cases per year in the United States. ${ }^{1}$ As such, decisive data are lacking, although it is clear that $O S$ is relatively poor with a generally accepted mean of $>3$ years. ${ }^{27}$ A minimum dose of 60 Gy is recommended. ${ }^{30-32,37,38}$

\section{Are there prospective data to guide the treatment of meningiomas in the modern era?}

Rogers, RTOG 0539 (Low Risk, ASTRO 2016, LBA 7; Intermediate Risk, J Neurosurg 2018, PMID 28984517; High Risk, IJROBP 2020, PMID 31786276): RTOG 0539 was the first prospective trial guiding the use of RT for meningiomas. Three risk groups were defined: low, intermediate, and high (see Table 4.5). Conclusion: This trial supports observation for low-risk patients and $54 \mathrm{~Gy}$ for intermediate-risk patients. WHO grade I patients s/p STR may warrant adjuvant RT (crude failure rate $40 \%$ ). 
TABLE 4.5: RTOG 0539 Summary

\begin{tabular}{|c|c|c|c|c|}
\hline Risk Group & Definition & EBRT Dose & Target Volume & Outcomes \\
\hline Low $(n=63)$ & $\begin{array}{l}\text { WHO grade I } \\
\text { meningioma s/p GTR } \\
\text { or STR }\end{array}$ & Observation & $\mathrm{N} / \mathrm{A}$ & $\begin{array}{l}\text { 5-yr PFS: } 86.1 \% \\
\text { 5-yr LF: } 12.5 \% \\
\text { (preliminary) }\end{array}$ \\
\hline $\begin{array}{l}\text { Intermediate } \\
(n=48)\end{array}$ & $\begin{array}{l}\text { WHO grade II } \\
\text { meningioma s/p GTR } \\
\text { Recurrent WHO grade } \\
\text { I meningioma }\end{array}$ & $54 \mathrm{~Gy} / 30 \mathrm{fx}$ & $\begin{array}{l}\text { Tumor bed }+1 \\
\mathrm{~cm} \text { CTV, reduced } \\
\text { to } 5 \mathrm{~mm} \text { around } \\
\text { barriers }\end{array}$ & $\begin{array}{l}\text { 3-yr PFS: } 93.8 \% \\
\text { 3-yr LF: } 4.1 \%\end{array}$ \\
\hline \multirow[t]{2}{*}{ High $(n=51)$} & \multirow{2}{*}{$\begin{array}{l}\text { WHO grade III } \\
\text { meningioma (any } \\
\text { resection) } \\
\text { WHO grade II } \\
\text { meningioma s/p STR } \\
\text { Recurrent WHO grade } \\
\text { II meningioma }\end{array}$} & \multirow{2}{*}{$\begin{array}{l}60 \text { Gy / } 30 \\
\text { fx (HD } \\
\text { PTV) with } \\
\text { simultaneous } \\
\text { low-dose } \\
\text { PTV 54 Gy }\end{array}$} & $\begin{array}{l}\text { HD PTV: gross } \\
\text { tumor }+ \text { resection } \\
\text { bed }+1 \mathrm{~cm}\end{array}$ & \multirow[t]{2}{*}{$\begin{array}{l}\text { 3-yr PFS: } 59.2 \% \\
\text { 3-yr LF: } 31.1 \% \\
\text { 3-yr OS: } 78.6 \%\end{array}$} \\
\hline & & & $\begin{array}{l}\text { LD PTV: gross } \\
\text { tumor }+ \text { resection } \\
\text { bed }+2 \mathrm{~cm}\end{array}$ & \\
\hline
\end{tabular}

Weber, EORTC 22042-26042 (Radiother Oncol 2018, PMID 29960684): Single-arm phase II study of 56 patients with grade II meningioma s/p GTR and RT 60 Gy/30 fx designed to show 3-year PFS $>70 \%$. With MFU 5.1 years, 3-year PFS was $88.7 \%$ and OS was $98.2 \%$. Late grade $\geq 3$ toxicity was 14.3\%. Conclusion: Grade II meningioma s/p GTR and $60 \mathrm{~Gy} / 30 \mathrm{fx}$ results in PFS of $88.7 \%$. Note: Observational cohorts of grade II meningiomas s/p STR and grade III meningiomas s/p any extent of resection have not yet been reported.

\section{How frequently should patients be surveyed following treatment for meningioma?}

For WHO grades I and II or unresected meningiomas, the 2020 NCCN guidelines recommend surveillance imaging with contrast-enhanced MRI at 3, 6, and 12 months, then every 6 to 12 months for 5 years, then every 1 to 3 years thereafter as clinically indicated. More frequent imaging may be required for WHO grade III and for any grade treated for recurrence or with $\mathrm{CHT}$.

\section{Should patients previously treated with RT be screened for meningioma?}

No. The incidence of clinically relevant meningioma in patients with a history of cranial RT is approximately $3 \%$ at 30 years from the time of RT..$^{33}$ The incidence of any meningioma in patients with no history of cranial RT may be as high as approximately $13 \%$ at 10 years. ${ }^{34}$ The incidence may reach $20 \%$ in patients with previous cranial RT who undergo screening with MRI at 20 years following RT. ${ }^{36}$ The estimated risk of neoplastic transformation from modern, highly conformal or SRS techniques is low at approximately 1 in 1,000. ${ }^{39}$ Therefore, a multidisciplinary working group in the United Kingdom has advised against screening as the risks of anxiety from serial MRI examinations and potential knowledge of an asymptomatic (and sometimes unresectable) tumors outweigh the benefits. ${ }^{40}$

\section{What dose of SRS should be used to treat meningioma and what are the outcomes?}

Similar to brain metastases, SRS dose depends on the volume being treated and the dose to adjacent critical structures. Mean doses generally have ranged from 16 to $24 \mathrm{~Gy}$, depending on location, with $>20$ Gy associated with higher rates of LC..$^{16,41,42}$ Maximal dose for cavernous sinus meningiomas is 12 to $14 \mathrm{~Gy}$, with doses $>18 \mathrm{~Gy}$ associated with unacceptable CN toxicity. ${ }^{43-45}$ Fractionated SRT with BED $>50$ Gy may decrease toxicity rates for patients in whom critical structures limit SRS dose. ${ }^{46}$ Most SRS series report excellent LC, with 10-year rates ranging from $>90 \%$ for WHO grade I to $>60 \%$ for WHO grades II and III. ${ }^{41,47-49}$

\section{What is meningiomatosis and how should it be managed?}

Meningiomatosis is commonly associated with NF or MEN syndromes. Treatment should be coordinated in a multidisciplinary fashion, with surgery given primary consideration due to concerns of secondary malignancy induction. RT is indicated for surgically unresectable or recurrent lesions. ${ }^{50}$ 


\section{REFERENCES}

1. Ostrom QT, Gittleman H, Fulop J, et al. CBTRUS Statistical Report: primary brain and central nervous system tumors diagnosed in the united states in 2008-2012. Neuro Oncol. 2015;17 Suppl 4:iv1-iv62. doi:10.1093/neuonc/nov189

2. Wiemels J, Wrensch M, Claus EB. Epidemiology and etiology of meningioma. J Neurooncol. 2010;99(3):307-314. doi:10.1007/s11060-010-0386-3

3. Marosi C, Hassler M, Roessler K, et al. Meningioma. Crit Rev Oncol Hematol. 2008;67(2):153-171. doi:10.1016/j. critrevonc.2008.01.010

4. Asgharian B, Chen YJ, Patronas NJ, et al. Meningiomas may be a component tumor of multiple endocrine neoplasia type 1. Clin Cancer Res. 2004;10(3):869-880. doi:10.1158/1078-0432.CCR-0938-3

5. Jhawar BS, Fuchs CS, Colditz GA, Stampfer MJ. Sex steroid hormone exposures and risk for meningioma. J Neurosurg. 2003;99(5):848-853. doi:10.3171/jns.2003.99.5.0848

6. Benson VS, Pirie K, Green J, et al. Lifestyle factors and primary glioma and meningioma tumours in the Million Women Study cohort. Br J Cancer. 2008;99(1):185-190. doi:10.1038/sj.bjc.6604445

7. Johnson DR, Olson JE, Vierkant RA, et al. Risk factors for meningioma in postmenopausal women: results from the Iowa Women's Health Study. Neuro Oncol. 2011;13(9):1011-1019. doi:10.1093/neuonc/nor081

8. Wiedmann M, Brunborg C, Lindemann K, et al. Body mass index and the risk of meningioma, glioma and schwannoma in a large prospective cohort study (The HUNT Study). Br J Cancer. 2013;109(1):289-294. doi:10.1038/ bjc. 2013.304

9. Niedermaier T, Behrens G, Schmid D, et al. Body mass index, physical activity, and risk of adult meningioma and glioma: A meta-analysis. Neurology. 2015;85(15):1342-1350. doi:10.1212/WNL.0000000000002020

10. Custer BS, Koepsell TD, Mueller BA. The association between breast carcinoma and meningioma in women. Cancer. 2002;94(6):1626-1635. doi:10.1002/cncr.10410

11. Sahm F, Schrimpf D, Stichel D, et al. DNA methylation-based classification and grading system for meningioma: a multicentre, retrospective analysis. Lancet Oncol. 2017;18(5):682-694. doi:10.1016/S1470-2045(17)30155-9

12. Suppiah S, Nassiri F, Bi WL, et al. Molecular and translational advances in meningiomas. Neuro Oncol. 2019;21 (Suppl 1):i4-i17.

13. Raizer J. Meningiomas. Curr Treat Options Neurol. 2010;12(4):360-368. doi:10.1007/s11940-010-0081-x

14. Anvari K, Hosseini S, Rahighi S, et al. Intracranial meningiomas: prognostic factors and treatment outcome in patients undergoing postoperative radiation therapy. Adv Biomed Res. 2016;5:83. doi:10.4103/2277-9175.182214

15. Durand A, Labrousse F, Jouvet A, et al. WHO grade II and III meningiomas: a study of prognostic factors. J Neurooncol. 2009;95(3):367-375. doi:10.1007/s11060-009-9934-0

16. Stafford SL, Perry A, Suman VJ, et al. Primarily resected meningiomas: outcome and prognostic factors in 581 Mayo Clinic patients, 1978 through 1988. Mayo Clin Proc. 1998;73(10):936-942. doi:10.4065/73.10.936

17. Pasquier D, Bijmolt S, Veninga T, et al. Atypical and malignant meningioma: outcome and prognostic factors in 119 irradiated patients. A multicenter, retrospective study of the Rare Cancer Network. Int J Radiat Oncol Biol Phys. 2008;71(5):1388-1393. doi:10.1016/j.ijrobp.2007.12.020

18. Yang SY, Park CK, Park SH, et al. Atypical and anaplastic meningiomas: prognostic implications of clinicopathological features. J Neurol Neurosurg Psychiatry. 2008;79(5):574-580. doi:10.1136/jnnp.2007.121582

19. Cai DX, Banerjee R, Scheithauer BW, et al. Chromosome 1p and 14q FISH analysis in clinicopathologic subsets of meningioma: diagnostic and prognostic implications. J Neuropathol Exp Neurol. 2001;60(6):628-636. doi:10.1093/ jnen/60.6.628

20. Vranic A, Popovic M, Cor A, et al. Mitotic count, brain invasion, and location are independent predictors of recurrence-free survival in primary atypical and malignant meningiomas: a study of 86 patients. Neurosurgery. 2010;67(4):1124-1132. doi:10.1227/NEU.0b013e3181eb95b7

21. NCCN Clinical Practice Guidelines in Oncology: Central Nervous System Cancers 3.2020. National Comprehensive Cancer Network; 2020. https:/ / www.nccn.org/professionals/physician_gls/pdf/cns.pdf. Accessed September 24.

22. Videtic GMM. Handbook of Treatment Planning in Radiation Oncology, 3rd ed. Demos Medical; 2020. doi:10.1891/9780826168429

23. Yano S, Kuratsu J, Kumamoto Brain Tumor Research G. Indications for surgery in patients with asymptomatic meningiomas based on an extensive experience. J Neurosurg. 2006;105(4):538-543. doi:10.3171/jns.2006.105.4.538

24. Simpson D. The recurrence of intracranial meningiomas after surgical treatment. J Neurol Neurosurg Psychiatry. 1957;20(1):22-39. doi:10.1136/jnnp.20.1.22

25. Komotar RJ, Iorgulescu JB, Raper DM, et al. The role of radiotherapy following gross-total resection of atypical meningiomas. J Neurosurg. 2012;117(4):679-686. doi:10.3171/2012.7.JNS112113

26. Press RH, Prabhu RS, Appin CL, et al. Outcomes and patterns of failure for grade 2 meningioma treated with reduced-margin intensity modulated radiation therapy. Int J Radiat Oncol Biol Phys. 2014;88(5):1004-1010. doi:10.1016/j.ijrobp.2013.12.037

27. Perry A, Scheithauer BW, Stafford SL, Lohse CM, Wollan PC. "Malignancy" in meningiomas: a clinicopathologic study of 116 patients, with grading implications. Cancer. 1999;85(9):2046-2056. doi:10.1002/ (SICI)1097-0142(19990501)85:9\%3C2046::AID-CNCR23\%3E3.0.CO;2-M

28. Miralbell R, Linggood RM, de la Monte S, et al. The role of radiotherapy in the treatment of subtotally resected benign meningiomas. J Neurooncol. 1992;13(2):157-164. doi:10.1007/BF00172765 
29. Rogers L, Barani I, Chamberlain M, et al. Meningiomas: knowledge base, treatment outcomes, and uncertainties. A RANO review. J Neurosurg. 2015;122(1):4-23. doi:10.3171/2014.7.JNS131644

30. Sughrue ME, Sanai N, Shangari G, et al. Outcome and survival following primary and repeat surgery for World Health Organization Grade III meningiomas. J Neurosurg. 2010;113(2):202-209. doi:10.3171/2010.1.JNS091114

31. Boskos C, Feuvret L, Noel G, et al. Combined proton and photon conformal radiotherapy for intracranial atypical and malignant meningioma. Int J Radiat Oncol Biol Phys. 2009;75(2):399-406. doi:10.1016/j.ijrobp.2008.10.053

32. Hug EB, Devries A, Thornton AF, et al. Management of atypical and malignant meningiomas: role of high-dose, 3D-conformal radiation therapy. J Neurooncol. 2000;48(2):151-160. doi:10.1023/A:1006434124794

33. Friedman DL, Whitton J, Leisenring W, et al. Subsequent neoplasms in 5-year survivors of childhood cancer: the Childhood Cancer Survivor Study. J Natl Cancer Inst. 2010;102(14):1083-1095. doi:10.1093/jnci/djq238

34. Muller HL, Gebhardt U, Warmuth-Metz M, et al. Meningioma as second malignant neoplasm after oncological treatment during childhood. Strahlenther Onkol. 2012;188(5):438-441. doi:10.1007/s00066-012-0082-7

35. Aghi MK, Carter BS, Cosgrove GR, et al. Long-term recurrence rates of atypical meningiomas after gross total resection with or without postoperative adjuvant radiation. Neurosurgery. 2009;64(1):56-60; discussion 60. doi:10.1227/01.NEU.0000330399.55586.63

36. Banerjee J, Paakko E, Harila M, et al. Radiation-induced meningiomas: a shadow in the success story of childhood leukemia. Neuro Oncol. 2009;11(5):543-549. doi:10.1215/15228517-2008-122

37. Dziuk TW, Woo S, Butler EB, et al. Malignant meningioma: an indication for initial aggressive surgery and adjuvant radiotherapy. J Neurooncol. 1998;37(2):177-188. doi:10.1023/A:1005853720926

38. Kaur G, Sayegh ET, Larson A, et al. Adjuvant radiotherapy for atypical and malignant meningiomas: a systematic review. Neuro Oncol. 2014;16(5):628-636. doi:10.1093/neuonc/nou025

39. Niranjan A, Kondziolka D, Lunsford LD. Neoplastic transformation after radiosurgery or radiotherapy: risk and realities. Otolaryngol Clin North Am. 2009;42(4):717-729. doi:10.1016/j.otc.2009.04.005

40. Sugden E, Taylor A, Pretorius P, et al. Meningiomas occurring during long-term survival after treatment for childhood cancer. JRSM open. 2014;5(4):2054270414524567. doi:10.1177/2054270414524567

41. Kano H, Takahashi JA, Katsuki T, et al. Stereotactic radiosurgery for atypical and anaplastic meningiomas. $J$ Neurooncol. 2007;84(1):41-47. doi:10.1007/s11060-007-9338-y

42. Choi CY, Soltys SG, Gibbs IC, et al. Cyberknife stereotactic radiosurgery for treatment of atypical (WHO grade II) cranial meningiomas. Neurosurgery. 2010;67(5):1180-1188. doi:10.1227/NEU.0b013e3181f2f427

43. Lee JY, Niranjan A, McInerney J, et al. Stereotactic radiosurgery providing long-term tumor control of cavernous sinus meningiomas. J Neurosurg. 2002;97(1):65-72.

44. Spiegelmann R, Cohen ZR, Nissim O, et al. Cavernous sinus meningiomas: a large LINAC radiosurgery series. $J$ Neurooncol. 2010;98(2):195-202.

45. Skeie BS, Enger PO, Skeie GO, et al. Gamma knife surgery of meningiomas involving the cavernous sinus: longterm follow-up of 100 patients. Neurosurgery. 2010;66(4):661-668; discussion 668-669.

46. Arvold ND, Lessell S, Bussiere M, et al. Visual outcome and tumor control after conformal radiotherapy for patients with optic nerve sheath meningioma. Int J Radiat Oncol Biol Phys. 2009;75(4):1166-1172. doi:10.1016/j. ijrobp.2008.12.056

47. Lee JY, Niranjan A, McInerney J, et al. Stereotactic radiosurgery providing long-term tumor control of cavernous sinus meningiomas. J Neurosurg. 2002;97(1):65-72. doi:10.3171/jns.2002.97.1.0065

48. Spiegelmann R, Cohen ZR, Nissim O, et al. Cavernous sinus meningiomas: a large LINAC radiosurgery series. $J$ Neurooncol. 2010;98(2):195-202. doi:10.1007/s11060-010-0173-1

49. Skeie BS, Enger PO, Skeie GO, et al. Gamma knife surgery of meningiomas involving the cavernous sinus: long-term follow-up of 100 patients. Neurosurgery. 2010;66(4):661-668; discussion 668-669. doi:10.1227/01. NEU.0000366112.04015.E2

50. Wentworth S, Pinn M, Bourland JD, et al. Clinical experience with radiation therapy in the management of neurofibromatosis-associated central nervous system tumors. Int J Radiat Oncol Biol Phys. 2009;73(1):208-213. doi:10.1016/j. ijrobp.2008.03.073 